\title{
Evaluering van verskillende gemeenteboumodelle met die oog op die daarstelling van 'n eie model vir die Nederduitsch Hervormde Kerk van Afrika
}

\author{
M J du P Beukes \\ Universiteit van Pretoria
}

\begin{abstract}
Evaluation of different congregation-development models with a view of introducing a model for the Nederduitsch Hervormde Kerk van Afrika

Since 1982 congregation development has been offered as a subject in most of the recognized practical theology departments. Certain factors have given rise to the fact that this subject and its practical application have not yet established themselves in the Nederduitsch Hervormde Kerk van Afrika. Scientific, systematic, goal-orientated planning and leading of a congregation in the light of the current situation in many congregations of the church have become absolutely essential. This article is an attempt to look into the evaluation of the Dreyer, Nel, Hendriks and Callahan congregation-development models with a view to develop a model for the Nederduitsch Hervormde Kerk van Afrika.
\end{abstract}

\section{PROBLEEMSTELLING}

Hoewel die vak Gemeentebou vanaf 1982 in die meeste erkende Praktiese Teologie departemente aangebied word (Möller 1987:74), besef baie predikante en kerkrade van baie kerke nog nie die waarde daarvan nie. Beide in teologiese debatvoering en op gemeentelike vlak het hierdie vak en sy resultate nog nie in die Nederduitsch Hervormde Kerk van Afrika tot sy reg gekom nie. Verskillende redes kan vir hierdie situasie aangevoer word:

* Beide die saak en begrippe wat in verband met gemeentebou gebruik word, is vir sommige predikante en lidmate onaanvaarbaar. Dit word beskryf as in stryd met die tradisionele beskouing en funksionering van kerkwees. Veral die bestuursmatige in die proses word afgewys;

* die proses van gemeentebou het in enkele gemeentes meer negatiewe as positiewe resultate tot gevolg gehad; 
* die beskrywing van die inhoud en die proses van gemeentebou is in baie gevalle so omslagtig, omvangryk en verwarrend dat daar onduidelikheid bestaan oor wat presies met gemeentebou bedoel word en dat sommige gemeentes daarom doodgewoon net nie daarvoor kans sien nie;

* verskillende gemeenteboumodelle is onveranderd en onkrities oorgeneem sonder dat deeglike evaluasie daarvan gedoen is en dit aangepas is om in ' $n$ bepaalde kerk se tradisie en behoeftes te voorsien;

* predikante en ander kerkleiers is nie goed opgelei om die proses van gemeentebou te bestuur nie; en

* basisteorieë en praktykteorieë is nie geformuleer voordat daar met die proses van gemeentebou in gemeentes begin is nie.

\section{WAT IS GEMEENTEBOU?}

Die wortels van gemeentebou word in die Bybel gevind. In beide die Ou en Nuwe Testament funksioneer die saak van gemeentebou sterk (Bisschoff 1991).

Die Hebreeuse woord דָָָָ ('bou') funksioneer veral prominent in die konteks van die verbond. Die ondertoon is telkens God se verkiesende genade (Hendriks 1987:3). In 'n milieu van voortdurende oorloë, waar afbreek en uitruk deurlopend voorkom, is die metafoor van heropbou vir Israel 'n sterk boodskapdraende konsep. Die ongeveer 390 voorkomende gevalle van die stam van die werkwoord 'om te bou' in die Ou Testament, is in die meeste gevalle beeldspraak om aan God se heilshandelinge en die negatiewe sy daarvan uitdrukking te gee. Die soewereine God is aan die werk. Hy bou sy volk, maar breek hulle ook af, as dit sy wil is. Hy bou hulle op ter wille van sy Naam, om volk te wees volgens sy bedoeling en om te dien as lig vir die nasies (Nel 1987:47). Die profete Amos, Jeremia en Esegiël fokus sterk op die Messias wat in die volheid van die tyd die werklike herstellende bouwerk aan die tempel (die volk van God) sou doen. Hierdie bouwerk sou met die lyding van die Kneg van die Here en sondevergewing gepaard gaan (Jer 31:34; Eseg 36:35; Sag 3:3-5; Jes 52:13-53:12). In Joh 2:19, Matt 16:18 en Mark 14:57-62 word verklaar en bevestig dat Jesus Christus as tempelbouer die Messias is. Nie die krag van mense nie, maar alleen die krag van die Heilige Gees sou die verbondsvolk in staat stel om hulle roeping te vervul (Sag 4:6).

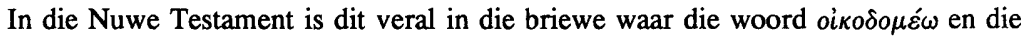
begrip 'bou' ' $n$ belangrike plek inneem. Verskeie kere word van die gemeente van Christus gepraat as bouwerk, 'n gebou, 'n huis of tempel (o a 1 Kor 3 en Ef 2). Die gemeente is God se eie bouwerk (1 Kor 3:9). Hierdie bouwerk verrig Hy deur die dienswerk van gelowige mense. Paulus was onder andere as 'n kundige boumeester daarmee besig ( 1 Kor 3:10; 2 Kor 10:8; Gal 2:18). Hierdie bouwerk moet op die 
fondament Jesus Christus geskied (1 Kor 3:11; Ef 2:10). Die gelowiges word ook opgeroep om mekaar onderling op te bou (Ef 4:16, 29; 1 Tess 5:11; Rom 14:19; 15:2, Jud 1:20). "Met die begrip "oikodomeo" word een opbouw-activiteit aangeduid, de primair het werk van God en Christus is, en vervolgens ook het werk van apostelen en andere evangeliepredikers en van iedere christen' (Te Velde 1989:7). Hierdie bouwerk is primêr gerig op die begeleiding van die gemeente om te wees wat dit reeds in Christus is (Ridderbos 1973:496). Dit is 'n dinamiese, doelgerigte proses waarvan Christus die grondslag gelê het, en word deur die werking van die Heilige Gees voortgesit tot by Christus se wederkoms. Samevattend stel Te Velde (1989:8):

De opbouw heeft twee zijden. Het is een toebrengen tot de gemeente van hen die tot nu toe buiten stonden (Rom 15:20vv.) en het is ook een bevestigen, versterken en volmaken van hen die reeds tot de gemeente behoren (1 Kor 14:3, 1 Tess 5:11, Kol 2:6-8, Ef 4:12-16). Deze beide lijnen kunnen worden aangeduid als intensieve en extensieve gemeenteopbouw, ook wel 'bewaren en vermeerderen' (Heidelbergse Catechismus zondag 48). Er is in de Schrift geen concurrentie van de twee motieven en ook geen prioriteit van het een boven het ander, maar ze staan in een onlosmaaklijke samenhang en wisselwerking met elkaar. De gemeente wordt niet pas missionair in een apart stukje verkondiging naar buiten, maar ze is in alle aspecten van haar bestaan missionair. En haar bevestiging en versterking in het evangelie heeft niet alleen een interne betekenis, maar is ook voor haar externe missionaire taak van het grootste belang.

Malan Nel sluit baie nou by Te Velde aan. Vir hom is gemeentebou die koördinering, integrering en verdieping van alle bedieninge in diens van die kommunikasie van die evangelie van Jesus Christus in diens van God, van mekaar en van die wêreld. Hierdie kommunikasie geskied deur die marturia, kerugma, leitourgia, paraklese, didache, kybernetiek, koinonia en diakonia (Nel 1994:96). Dit is niks anders as doelgerigte, planmatige, toegewyde bediening met die oog op die kerk se apostolaat, pastoraat en diakonaat nie. Hierdie intensiewe bediening is gawe van God, maar tegelyk is dit opdrag van God. Hierdie opdrag realiseer primêr deur die Woord van God en die Heilige Gees. Vir hierdie doel gebruik die Gees die ampte en die lidmate van die gemeente (Raubenheimer 1987:42-51).

In die loop van die twintigste eeu, veral die laaste twintig jaar, het die begrip gemeentebou (Gemeindeaufbau, parish development) besondere klem gekry. Onder invloed van die sosiologie, didaktiek en sielkunde is aan die begrip gemeentebou hoe langer hoe meer besondere betekenis gegee. Gemeentebou is al hoe meer gesien as 'n 
bewustelike, sistematiese, strukturele, kritiese, planmatige, metodiese wyse om 'n gemeente te begelei vanuit 'n bepaalde situasie, veral stagnante situasie, tot ' $n$ ideale funksionering soos dit behoort te wees. Gemeentebou kan in die lig hiervan in praktyk beskryf word:

as die bediening waardeur die gemeente opgelei en begelei word om sy eie wese en doel te verstaan; self, as gemotiveerde gemeente, sy eie funksionering te evalueer, doelwitte vir sy doelgerigte funksievervulling te formuleer en op beplande wyse te bereik; self soos nodig, op 'n voortgaande basis strukture, wat die heilshandelinge van die drie-enige God in kerk en wêreld dien, vir die gemeentelike funksionering te ontwikkel.

(Nel 1994:14)

Met die oog op hierdie wetenskaplike, sistematiese, doelmatige beplanning en begeleiding van 'n gemeente, het gemeentebou as 'n selfstandige vak in die Praktiese Teologie ontwikkel. Dit het aanvanklik gefunksioneer onder die name oikodomiek en pastoralekybernetiek. Beide hierdie benaminge het gaandeweg plek gemaak vir die benaming gemeentebou of gemeente-opbou (Herbst 1988:72; kyk ook Kuyper 1909:530-535). Volgens Te Velde (1989:10) kom die saak van gemeentebou en aanwysings oor gemeentebou reeds by die 'apostoliese vaders', die oud-Christelike kerk en die hervormers Luther, Bucer en Calvijn voor. Die vak gemeentebou het egter sy oorsprong in die periode 1870 tot 1930 in die werke van die Duitse teoloë soos J H Wichern en B Gutmann. Sedert 1982 word hierdie vak deur feitlik alle erkende Praktiese Teologie departemente in Nederland, Duitsland, Amerika en Suid-Afrika gedoseer. In die Nederduitsch Hervormde Kerk van Afrika het die saak van gemeentebou nog altyd indirek bestaan as inbegrepe by kerkvisitasie en deurlopende verslaggewing aan meerdere vergaderings. Veral die Werkgroep Gemeente-opbou en sy rade was deur die jare in die besonder diensbaar aan hierdie saak. Sedert 1985 word gemeentebou as deel van die vak Praktiese Teologie aan die teologiese fakulteit van die kerk gedoseer. Gebrek aan mannekrag en ander faktore het egter daartoe gelei dat hierdie vak nog nie besondere hoogtes in die kerk bereik het nie.

In die vak gemeentebou vind teologiese besinning plaas oor hoe die gemeentestrukture, die werkvorme en prosesse in optimale samehang diensbaar gemaak kan word aan die interne en eksterne, die horisontale en vertikale funksionering van die kerk tot eer van God, tot opbou van die gemeente en tot diens aan die wêreld (Nel 1987:3).

In gemeentebou neem die gemeente of die kerkgroep se ekklesiologiese beskouings 'n sentrale plek in. 'n Bepaalde gemeente se beskouing van kerkwees, bepaal grootliks hoe die gemeente se gemeentebouproses gaan lyk. In hierdie verband onderskei Te 
Velde (1989:12-22) vyf kerkbeskouings wat gedurende die laaste tien jaar prominent na vore gekom het. Hierdie beskouings van kerkwees het grootliks daartoe bygedra dat gemeentebou deur baie teoloë negatief bejeën word. Hy verwys na die volgende:

* de oecumenisch-apostolair georiënteerde gemeente;

* de corporatief-exemplarisch georiënteerde gemeente;

* de conciliair-pluralistisch gemeente;

* de evangelicaal-methodistisch gemeente; en

* de missionair-volkskerklijke gemeente.

Ekumenies-apostolêre gemeentes het veral sedert Kraemer se magistrale werk oor dienswerk van die gelowiges en die Wêreldraad van Kerke se beraad in New Delhi in 1961 na vore gekom. Die volgorde is hier nie God - kerk - wêreld nie, maar God wêreld - kerk. Kerk en wêreld word hier feitlik een. Kenmerke soos openheid, sosiale relevansie, vryheid, diensbaarheid en solidariteit met mens en wêreld staan voorop. Die apostolaat en diakonaat verslind hier die pastoraat geheel en al. Die opbou na buite is alles en die opbou na binne feitlik niks.

Die korporatief-eksemplariese gemeentes hou die opsie vir 'n gerigtheid na buite oop, maar stel die unieke van die eie kerk en gemeente voorop. Begrippe soos bewaring, tradisie, eie etos speel hier 'n oorheersende rol. Die bewaring van die eie word belangriker as die verkondiging van Jesus Christus. Die pastoraat laat die apostolaat en die diakonaat feitlik geheel en al verdwyn.

Die concilair-pluralistiese gemeentes laat val die klem baie sterk op die pluraliteit van die kerk. Feitlik alle menings en sienings het hier bestaansreg. Die gemeente is 'n oop leergemeenskap wat telkens opnuut die waarheid deur dialoog binne elke situasie moet ontdek. Die waarheid is nooit 'n vaste gegewene nie (Bons-Storm 1987:114115). Hierdie pluraliteit kan herlei word tot 'n bepaalde beskouing van die kanon, naamlik dat die Bybel slegs ' $n$ versameling van verskillende menslike getuienisse is.

Die evangelicaal-methodistisch rigting in gemeentebou het in die vyftigerjare in Amerika ontstaan en vandaar oor feitlik die hele wêreld versprei. Kenmerkend van hierdie churchgrowth movement is die wen van duisende mense vir die evangelie deur middel van groot kampanjes, vereenvoudiging van die Bybelse boodskap, deurlopende oproep tot persoonlike bekering en die benutting van goed deurdenkte en beplande tegnieke om die werk van die kerk te doen. Groot klem word geplaas op Bybelstudie, geloofsoefening en die dienswerk van die gelowiges. Die drang na getalle en ' $n$ byna kommersiële benadering van die evangelisasie-aksies is sterk oorheersend. 'Een heilige, levende gemeente is hier het doel' (Te Velde 1989:16). 
Die missionair-volkskerklijke is in baie opsigte net so mensmiddelpuntig en horisontalisties soos die ander strominge. Hoewel die aanvanklike grondleggers van hierdie beskouing se gedagte was om die evangelie by die hele volk uit te bring, het dit in die meeste gevalle verword tot ' $n$ bediening waar die eie volk verabsoluteer is en ander volke uitgesluit is. Die handhawing van die eie het belangriker geword as die bediening van die evangelie aan die wêreld. Politiek het teologie begin oorheers.

Op Suid-Afrikaanse bodem is dit veral Malan Nel (1994), Jurgens Hendriks (1992) en Jan Bisshoff (1991) wat 'n leidende rol gespeel het ten opsigte van die fundering, die vestiging en die uitbouing van gemeentebou. Hierdie drie teoloë gee elkeen aan gemeentebou 'n sterk teologiese basis en word 'n ekklesiologie, wat in Reformatoriese kringe ten volle aanvaarbaar is, as vertrekpunt geneem.

\section{EVALUERING VAN VERSKILLENDE GEMEENTEBOUMODELLE}

Uit die aard van die saak is dit onmoontlik om alle bestaande gemeenteboumodelle te evalueer. Dit is selfs onmoontlik om alle modelle in bepaalde kategorieë in te deel en dan van daaruit bepaalde afleidings te maak. In hierdie artikel gaan ek kortliks aandag gee aan die model van Dreyer, Callahan, Jurgens en Nel.

In 1987 het Dreyer (1987:54-70) 'n intensiewe evaluasie gemaak van die volgende gemeenteboumodelle: Dynamics of Church Growth (Christian Leadership Training Center, Philadelphia), Essentials of Discipleship (Navigators), Robert $C$ Girards Church Building (Our Heritage Wesleyan Church, Arizona), World Harvest Mission (New Life Church, Philadelphia) en Gemeentebou (Nederduitse Gereformeerde Kerk). Samevattend oordeel hy dat al die genoemde gemeenteboumodelle baie waardevol is, maar dat een belangrike aspek deurgaans ontbreek, naamlik die individuele motivering of houdingsfaset. Sonder hierdie motivering sal lidmate nie in staat wees om 'werklik in die geloof te groei nie'. Dit beteken dat lede geleer moet word om bewus te raak van hulle emosies en gevoelens. Die lidmate moet geleer word om hierdie selfondersoek te doen en ander te vra om daaraan deel te neem. Naas hierdie gebrek aan die opbou van die lidmaat se persoonlike verhouding met God, is daar vir hom die groot leemte van inoefening van vaardighede met die oog op die intrapersoonlike. Ook dit sal eers realiseer as vaardighede op die vlak van die intrapersoonlike ontwikkel is. 'Die kerk sal 'n groot klomp tyd en geld spaar indien hy eers op die intrapersoonlike vlak (geloofsgroei of heiligmaking) sy lidmate toerus voordat hy hulle wil toerus vir die werk vir 'n bepaade diensgroep' (Dreyer 1987:69). In feite beteken dit vir hom dat die basiese karaktertrekke wat in die lewe van 'n gelowige moet voorkom, operasioneel gedefinieer moet word en dan in 'n bykomende program ontwikkel moet word. Die bykomende waarna Dreyer vra, het hy self voorsien in sy gemeentebou-geloofsboukursus wat gesien kan word as 'n praktiese toepassing van sy proefskrif Building up the body of Christ. In hierdie kursus val die klem oorheersend op die intrapersoonlike. 
Alhoewel daar kritiek teen die inhoud van Dreyer se geloofsbou-gemeentebou program gelewer kan word, het hy 'n belangrike bydrae gelewer met die oog op sinvolle gemeentebou. Die kerk het 'n neiging om in 'n groot mate te fokus op die instituut as sodanig. Die funksionering van die gemeente as geheel, die groepe afsonderlik en die gesin as sodanig word so oorbeklemtoon dat die indivuduele verhouding met God geheel en al uit die oog verloor word. Wanneer die kerk oor homself in sy belydenisskrifte praat, is dit interessant dat beide die korporatiewe en die individuele gehandhaaf word - die gemeenskap van die gelowiges hef nie die individuele deelhê aan Christus en sy weldade op nie. Die roeping tot lewende lidmaat en verwesenliking van die gemeenskap van die gelowiges is 'n roeping wat gegrond is op die werk van die Heilige Gees en begin by persoonlike verantwoordelikheid (Heidelbergse Kategismus, Vraag en Antwoord 54 en 55). Dreyer se bydrae beteken dat in die motivering van 'n gemeente, die evaluering van 'n gemeente se funksionering, die skryf van doelwitte en die kies van bepaalde strategieë in 'n gemeentebouprogram, die intrapersoonlike beslis verreken sal moet word.

Waar Dreyer die intrapersoonlike sterk beklemtoon, doen Callahan (1987) dit ten opsigte van die korporatief-missionêre. In Callahan se denke neem gemeentebou 'n geweldige belangrike plek in. Sy navorsing en betrokkenheid by baie gemeentes se strategiese beplanning het daartoe gelei dat hy 'n gemeentelike beplanningsprogram ontwerp het (Callahan 1987) wat feitlik wêreldwyd met groot welslae benut word. Die kritiese suksesfaktore by die meeste goed funksionerende gemeentes dien as die basis vir sy evaluering en verdere beplanning van 'n gemeentebouprogram. Na deeglike motivering neem 'n wye spektrum gemeentelede deel aan 'n evaluering van die gemeente. 'n Realistiese beraming van die gemeente se huidige toestand en grootte word gemaak. In die lig van die gemeente se potensiaal en die potensiaal van groei in die omgewing word bepaal tot waar die gemeente wil en kan uitbrei. Hierna word die sterk punte van die gemeente bepaal in die lig van 'die twaalf sentrale kenmerke van effektiewe gemeentes' (Callahan 1987:11-34). Die sentrale kenmerke van effektiewe gemeentes word onderskei in relasionele en funksionele kenmerke. Onder die relasionele kenmerke word die volgende gereken: spesifieke, konkrete, missionêre doelwitte, pastorale besoeke deur pastors en lidmate in die gemeenskap, gemeenskaplike, dinamiese eredienste, betekenisvolle relasionele groepe, sterk leierskaphulpbronne, vaartbelynde strukture en deeglike deelnemende besluitneming. Die funksionele kenmerke van 'n gemeente is die volgende: Verskeie toereikende programme en aktiwiteite, openheid en toeganklikheid, opvallende sigbaarheid, voldoende parkering, grond en landskapsontwikkeling, voldoende ruimte en fasiliteite en gesonde finansiële hulpbronne. Die evaluering vind individueel in pare, deur ' $n$ tafel.se lede en uiteindelik 
deur die optelsom van al die lede se tafels plaas. Die evaluering vind plaas deur middel van 'n graderinggids waarin bepaalde kenmerke van die aspek wat geëvalueer word, opgenoem word met 'n sekere puntetoekenning. Hierna word voorstelle met die oog op beter funksionering (blink idees) gemaak. Daarna word die gemiddelde van elke gradering op 'n grafiek getrek. Twee of drie van die gemeente se huidige sterk punte word nou gekies om uit te bou. Nog twee of drie ander punte word gekies wat die gemeente die effe!.tiefste as sterk punte kan toevoeg. Sleuteldoelwitte word geformuleer en tydskedules vir die volgende paar jaar word opgestel. Hierna word 'n projekspan gekies wat die aspekte waarop besluit is, verder moet uitbou en bestuur.

Callahan bied 'n breë struktuur wat met enkele wysigings met groot vrug in gemeentes aangewend kan word. Daar is egter bepaalde aspekte wat gewysig sal moet word voordat dit 'n aanvaarde strategie vir die Nederduitsch Hervormde Kerk van Afrika sal wees. Die geweldige positiewe is die feit dat die missionêre deur en deur tot sy reg kom. Dit is veral hierdie aspek wat sterk positief benut kan word. Callahan se geskrifte $(1987,1994)$ bring aan die lig dat hy deurgaans goeie teologiese begronding vir sy praktykteorieë het. Hierdie teologiese fondament behoort egter gehandhaaf te bly, wanneer hy sy gemeentelike beplanningsmodel op die tafel sit. Die basiese kriteria behoort die teologies-prinsipiële te wees, en nie die empiries-effektiewe nie. Meting behoort plaas te vind nadat die doel van kerkwees prinsipieel bepaal is, en nie nadat empiries waargeneem is watter gemeentes effektief funksioneer nie. Dit bring in feite mee dat die belangrikste aspekte van kerkwees, soos onder andere die didache, ook gemeet sal moet word. As inhoudelik gekyk word na die meting van 'n bepaalde afdeling by Callahan, is dit nie die kwalitiewe of 'n gebalanseerde balans tussen die kwalitatiewe en die kwantitatiewe wat gemeet word nie, maar oorheersend die kwantitatiewe. Die keuse van wat uitgebou gaan word, word ook nie gemaak op grond van teologiese kriteria nie, maar bloot op grond van die neergelegde beginsel dat die uitbouing van reeds bestaande sterk punte, die grootste effek het. As hierdie beginsel op die meeste Reformatoriese kerke in Suid-Afrika toegepas word, sal dit doodgewoon beteken dat die kerk se missionêre roeping nog verder sal verwaarloos. Evaluering met teologiese kriteria as vertrekpunt sal egter meebring dat die missionêre telkens uitgewys sal word as die punt wat juis besonder aandag vra.

Vir Hendriks is gemeentebou slegs moontlik as dit teologies gefundeerd is. Dit is God self wat op grond van Christus se versoeningswerk met sy Gees sy gemeente opbou deur die werk van ampsdraers en lidmate tot eer van sy Naam en tot uitbreiding van sy koninkryk (Hendriks 1992:37-89). Die vertrekpunt van Hendriks se gemeentebouprogram is die ekklesiologie (Hendriks 1994:11-36). Eers as teologies bepaal is hoe die kerk behoort te lyk, kan gemeet word in watter mate 'n gemeente aan sy roe- 
ping voldoen. Die drie basiese ekklesiologiese paradigmas van hoogkerklik, laagkerklik en gereformeerd (Rossouw 1990:43-58) verfyn hy tot: die instituutmodel, die verkondigingsmodel, die liggaamsmodel en die transformasiemodel. Aan die hand van teologies-prinsipiële kriteria word die vier modelle geëvalueer. Hoewel Hendriks 'n baie sterk aanvoeling het vir die liggaammodel, kies hy eerder van elke model die positiewe. Nadat hy 'n deeglike studie gemaak het van die begrip 'opbou' in die Bybel, formuleer hy 'n basisteorie (Hendriks 1992:85). Met sy basişteorie as uitgangspunt formuleer hy sy praktykteorie. Hendriks kies vir 'n ekklesiologiese model wat hy die aanvullende koinonia-verbande noem. Hy stel die model voor in die vorm van 'n wiel. Christus se kruis is die middelpunt. Die individuele gelowige is die as, die wiellaers is die huwelik en die gesin, die naaf van die wiel is die verskillende kleingroepe in die gemeente, die speke van die wiel is bedieninge in groot groepe, die band van die wiel is die erediens en die koers wat die wiel gaan, is die wêreld. Soos voorgestel deur Dreyer (1986), kry die intrapersoonlike hier sy regmatige plek. Die huisgesin wat in die meeste kerklike bedieninge grootliks verwaarloos word (Louw 1989), kom hier ook tot sy reg. Groepwerk word nie oorbeklemtoon nie en die erediens kry nog steeds sy regmatige plek. Callahan se sterk pleidooi vir die kerk se missionêre gerigtheid kom ook ten volle tot sy reg. Met hierdie balans van die verskillende koinonia-verbande word drie groot gevare voorkom:

* As daar op die erediens ten koste van die ander verbande die klem gelê word, word die kerk geleidelik 'n organisasie, ' $n$ instituut. 'Dit duur uiters twee of drie geslagte en daardie kerk ondervind ' $n$ besliste daling in lidmaatgetalle en meelewing as gevolg van sy koudheid, verstoktheid, leweloosheid en formalisme' (Hendriks 1992:103);

* as die binneste drie sirkels, naamlik die individu, die gesin en die groepe oorbeklemtoon word, verval die kerk gewoonlik in een of ander vorm van piëtisme, die kleingroepies word klieks met ' $n$ soort hoogdrawende mentaliteit; en

* as die gerigtheid op die wêreld losgelaat word, bloei 'n kerk hom geleidelik dood om later meer 'n kultuurbastion as dienskneg van Jesus Christus te word.

$\mathrm{Na}$ die formulering van sy basisteorie en prinsipieel verantwoorde praktykteorie, gaan Hendriks oor tot die proses van sy gemeentelike beplanning. Uit sy strategieë is dit duidelik dat hy die proses van strategiese beplanning soos dit in die sekulêre wêreld voorkom, goed bemeester het en daarin geslaag het om dit te verwerk met die oog op kerklike bediening. In sy ontleding hou hy vas aan sy koinoniamodel. Dit beteken noodwendig dat die ontleding van die gemeente wat hy doen, baie breed loop. Die volgende aspekte van gemeentewees word ontleed: persoonlike geloofsoortuigings, huwe- 
lik, lidmaatgetalle, ouderdomsgegewens, beroepskategorieë, erediensbetrokkenheid, finansiële ontleding en funksionering van groepe (kyk Hendriks 1992:215-277). Die besonder positiewe van sy model is die feit dat alle aspekte van gemeentewees en veral die intrapersoonlike, die familiale en die gerigtheid op die wêreld deeglik in ag geneem word. Die omvattendheid van die proses kan egter daartoe lei dat die gemeente kan swig onder 'n oordosis statistiek. Die grootse beswaar teen Hendriks se model is die feit dat die meting nie plaasvind aan die hand van bepaalde kriteria nie. Na die ontleding volg beskrywing van die gemeentedoel, formulering van doelwitte en strategieë om die doelwitte te laat realiseer (Hendriks 1992:183-189). Die geringe plek wat aan hierdie laaste aspekte gegee word, kan daartoe lei dat die hele gemeentebou-program misluk.

Net soos Hendriks, sien Malan Nel gemeentebou as 'n teologies-wetenskaplike aktiwiteit. Sterk teologiese uitgangspunte is die basis waarop hy sy basis- en sy praktykteorieë bou (Nel 1987, 1988, 1994). Hoewel gemeentebou vir hom 'n baie sterk vernuwende prosesmatige gebeure is, is die gedagte van vernuwing, slegs ter wille van vernuwing, nie oorheersend nie (Nel 1993:118). Vernuwing word eerder gesien as 'n hervormingsproses waar die gemeente deur sy eie insigte oorgaan tot verandering om te word wat dit reeds in Christus is. Die interdissiplinêre koppeling van Praktiese Teologie met ander aanvaarde wetenskappe maak benutting van bestuursbeginsels in gemeentebou vir hom aanvaarbaar. Hy knoop aan by bekende beplanningmodelle soos dié van Lippit, Ten Have, Lissenburg, Seifert en Clinebell (Nel 1988) en kies die volgende as hoofkomponente vir sy beplanningsmodule: beplanning, organisering, leiding en kontrole. Kernkomponente in die beplanningsfase is ' $n$ baie duidelike omskrywing van die doel van kerkwees in die algemeen en van daaruit die formulering van 'n duidelike, kort gemeentelike visie (Nel 1994:145). Motivering, veral met benutting van die bestaande bedieningsmodi, bestaande strukture en moontlike nuwe projekte word deurlopend benut. In lyn met bestaande modelle vorm gemeente-analise 'n sentrale komponent van die hele gemeentebouproses. Soos in die meeste ander strategiese beplanningsmodelle word hier ook drie hoofsake op die tafel geplaas: die gemeenteprofiel, omgewingdiagnose en gemeentelike funksionering. Hierdie diagnose kan geskied deur vraelyste, gesprekke, groepbesprekings en ander moontlikhede. Dit is egter belangrik dat die evaluering deur die gemeente self plaasvind en dat alle aspekte

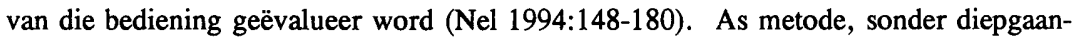
de motivering, beveel hy Callahan se metode en inhoude aan as bron van benutting deur 'n groep uit die gemeente wat vrywillig vir 'n aantal ure die ontleding doen. Die benutting van Callahan se model lei daartoe dat die baie stewige onderbou van Nel se proses op wankelrige voete te staan kom. 'n Geoefende teoloog wat goed bekend is 
met gemeentelike evaluering, soos Nel self, sal wel Callahan se model kan gebruik, maar nie iemand wat nie goed onderlê is nie. 'n Baie sterk punt van Nel is sy besondere beklemtoning van die skryf van realistiese haalbare doelwitte, goed deurdagte strategieë, goeie leiding en deurlopende kontrole ( $\mathrm{Nel} \mathrm{1994:181-266).}$

\section{GEMEENTEBOUMODEL VIR DIE NEDERDUITSCH HERVORMDE KERK VAN AFRIKA}

Daar is teoloë wat oordeel dat gemeentebou nie noodsaaklik vir die kerk se gemeentes is nie. Hulle oordeel dat die saak en baie aspekte daarvan vir die kerk vreemd is. Daar word veral beswaar gemaak teen die bestuursmatige wat die basiese struktuur van die proses vorm. Volgens hierdie teoloë moet die kerk onveranderd sy werk doen deur middel van die reeds bestaande bedieninge, veral die prediking en die bestaande strukture wat reeds in die Kerk se Kerkwet en bepalings voorgeskryf word (Breytenbach 1991:333). Aan die ander kant het 'n beduidende aantal predikante van die kerk deur middel van die enorme hoeveelheid literatuur op hierdie vakgebied kennis geneem van gemeentebou, reeds kursusse in gemeentebou deurloop of is daarmee besig by ander kerke se teologiese fakulteite of institute. In 'n aantal gemeentes is beplande gemeentebou ook reeds aan die gang. Indien al die gemeentes van die kerk hulle werk planmatig en goed gedoen het, sou nuwe strategieë wat beoog om die bestaande te orden en te verbeter, nie nodig gewees het nie. Verskillende aspekte in die kerk maak gestruktureerde gemeentebou noodsaaklik:

* Groot getalle gemeentes wat net nie meer die mas opkom nie.

* Baie predikante wat die bediening neerlê.

* Die totaal na binne-gerigtheid van gemeentes dui aan dat die kerk nie werklik besef wat sy roeping in die lig van die Woord is nie. Uit jaarverslae blyk dat gemeentes net groei deur die byvoeging van dooplidmate, maar nie deur evangelisasie nie.

* Gebrek aan beroepe dwing predikante om feitlik lewenslank in een gemeente te werk. Afgesien van gevolglike stagnasie, kan 'n predikant na 'n aantal jare sonder intensiewe beplanning en doelgerigte bediening net nie meer die mas opkom nie.

* Kerkleiers funksioneer in gemeentes nie volgens die gawes wat hulle ontvang het nie. In baie gemeentes is dit algemene praktyk dat die sterkste leiers nie in werkgroepe wat te doen het met die bediening van die Woord geplaas word nie, maar by die finansies.

* Pastor-gesentreerde gemeentes is bykans 'n algemene verskynsel.

* Die ampte funksioneer so oorheersend dat daar feitlik nie ruimte is vir dienswerk deur die gelowiges nie. 
* Gestolde strukture, die goeie ou dae dae-sindroom, is aan die orde van die dag en daar word nie rekening gehou met die nuutste teologiese ontwikkeling nie, veral nie op die terrein van die Praktiese Teologie nie.

* Nuwe omstandighede in die land en op plaaslike vlak word doodgewoon geïgnoreer.

* Die stagnante situasie in gemeentes het in baie gevalle daartoe aanleiding gegee dat vernuwing bloot ter wille van vernuwing ingevoer is. In baie gevalle is hierdie ongemotiveerde, planlose vernuwing niks anders as oppervlakkige foefies wat nie stand hou nie.

Aangesien God in sy Woord eis dat alles in die kerk ordelik moet verloop, sy kerk opgebou moet word en dit eintlik vanselfsprekend is dat elke gemeente na uitnemendheid behoort te strewe, bied bestaande gemeenteboumodelle met aanpassings om by ons eie kerk se etos te pas, besondere geleenthede om die kerk en gemeentes te begelei om te wees wat dit reeds in Christus is.

Met gemeentebou word nie allerlei nuwighede in die kerk ingevoer nie. Dit is 'n eerlike poging om die kerk op 'n wetenskaplike en planmatige wyse te lei om sy opdrag uit te voer. Dit kan beskryf word as 'n kerklike aktiwiteit om deur middel van die bestaande kommunikatiewe geloofshandelinge die gemeente te lei om te funksioneer ooreenkomstig sy wese tot eer van God, tot opbou van die gemeente en tot uitbreiding van God se koninkryk in die wêreld. Hierdie werk word gegrond op die Bybel, die belydenisskrifte en die bestaande kerklike bepalings. Die bestaande word gekoördineer, beter beplan, geïntensiveer en waar nodig, teruggelei om te wees soos God dit wil hê. Die inhoud bly steeds dieselfde, en al wat verander, is die metode en die feit dat bestuursbeginsels benut word. Die legitimiteit om data uit nie-teologiese dissiplines te benut, sonder dat teologiese beginsels in gedrang kom, is reeds lankal deur die kerk aanvaar. Die Christelike gemeente is ' $\mathrm{n}$ groep mense in die samelewing. ' $\mathrm{Zij}$ noemt zich naar Christus, maar is een sociale eenheid, georganiseerd volgens de wijze van redeneren die geldt in de hedendaagse cultuur in onze maatschappij' (Bons-Storm 1987:127). Die kerk is 'n lewende organisme wat sy lewe van God ontvang en tegelyk 'n organisasie van mense vir mense (Heyns 1993:128). Die kerk is tegelyk 'n pneumatiese en 'n menslike werklikheid. Vir die denke oor die kerk het dit belangrike implikasies. Die geestelike dimensie van die kerk lê bokant ons analise, dit is nie navorsbaar nie. Met die menslike kant is dit egter anders gesteld: dit is navorsbaar, bestuursmatig, beplanbaar en meetbaar. Die werk van die Gees in die kerk gee vir niemand verskoning om onbepland, traak-my-nie-agtig te werk nie. Die Heilige Gees sluit die mens nie uit nie, maar wil die mens met sy gawes juis in die kerk benut (Burger 1991:29). Aangesien die kerk in die wêreld is, oor 'n bepaalde struktuur moet 
beskik en daagliks moet funksioneer, is beplanning en bestuur noodsaaklik. Uit die geledere van die Nederduitsch Hervormde Kerk van Afrika het veral Botha (1985) aangetoon dat die beginsels van bedryfsleiding met groot vrug in die kerk benut kan word, sonder dat teologiese beginsels in gedrang kom.

Arnold Moll (in Heyns 1993:129-132) het 'n diepgaande studie van bestuursteorieë gemaak. Hy reduseer al die teorieë tot drie basiese teorieë: die tradisionele teorie, die menseverhoudingsteorie en die mensbenuttingsteorie. Al drie hierdie modelle kom in een of ander vorm in die kerk voor. Beide die tradisionele teorie en die mensverhoudingsteorie dra egter tendense van paternalisme, voorskriftelikheid en die hantering van die ander party as ondergeskikte. Hoewel daar nie 'n teologiese bestuursteorie bestaan nie, sal die mensbenuttingsteorie waarskynlik die beste pas in 'n kerk waar die presbiteriaal-sinodale beginsels geld en waar die liggaammodel funksioneer. Volgens hierdie teorie word aan die lidmate selfstandigheid gegee met die oog op hulle dienswerk in die wêreld. Die ampsdraers dien hier hoofsaaklik om die lidmate vir hulle dienswerk toe te rus (Heyns 1993:133).

\section{WATTER MODEL EN VORM}

Aangesien gemeentebou ' $n$ prosesmatige gebeure is, is een model nie sonder meer geskik vir alle situasies nie. Omdat die kerk 'n lewende organisme is, sal al die komponente wat ' $n$ invloed op ' $n$ alternatiewe moontlikheid meebring, verreken moet word. In die kerk behoort ruimte te wees vir die benutting van selfs meer as een model, afhangende van die gemeente se standi et vivendi en die persoon wat as fasiliteerder optree. Op hierdie terrein is talle modelle vir evaluering beskikbaar. Kruger (1980:23) het egter voldoende aangetoon dat die basiese beplanningsmodel van Ralph Tyler steeds die bruikbaarste is. Nadat Nel (1988:4-7) baie gemeenteboumodelle geëvalueer het, kom hy uiteindelik ook terug na die basiese model van: beplanning, organisering, leiding en kontrole.

\subsection{Beplanning}

\subsubsection{Motivering}

Motivering neem ' $n$ baie belangrike plek in 'n gemeentebouprogram in. Intensiewe gemeentebou begin eers werklik nadat dit voorafgegaan is deur ' $n$ intensiewe, doelbewuste en beplande motiveringsaksie. Motivering is egter nie net ' $n$ begin nie, maar 'n deurlopende komponent. Volgens Lissenburg (1978:23) moet daar met drie subdimensies van mondigheid in die motiveringsproses rekening gehou word: 'participatie', 'pluriformiteit' en 'solidariteit'. 'Participatie' beteken nie alleen dat gemeentelede mag deelneem nie, maar dat hulle kragtens hulle geloof in Christus daartoe verplig is. 
Die gemeente is nie 'n 'kleurlose eendersheid' nie, maar 'n 'pluri-formiteit', 'n ryke verskeidenheid waarin ruimte is vir verskillende insigte en bydraes (Nel 1993:123). Die 'solidariteit' beteken dat die gemeente in Christus bymekaar hoort en dat verskille en andersheid hulle nie van mekaar mag skei nie. 'Wat bind is sterker as wat mag skei' (Nel 1993:123).

Die vyf hoof motiveringsbronne in 'n gemeente is volgens Callahan (1987:76-83) 'compassion, community, challenge, reasonability en commitment'. Hoewel al die komponente vir motivering belangrik is, is die effektiefste 'compassion' en 'community'. Wat mense trek en motiveer is in die eerste plek nie 'n lesing of toerustingaktiwiteit nie, maar 'n gees van omgee en ruimte om opgeneem te word en deel te neem - selfverwesenliking. (Sien in die verband Maslow se behoefteteorie, soos aangehaal deur Dingemans 1986:109.)

Sodra die gemeente oortuig is dat verandering moet plaasvind, neem 'n intensiewe motiveringsproses ' $n$ aanvang. Gemeenteboukundiges noem dit ontvriesing (Nel 1988: 8). Hierdie motivering geskied deur die prediking en ander kommunikatiewe geloofshandelinge en aktiwiteite waarop besluit word. Die doel van die motivering is om die gemeente te lei om insig in sy eie wese te kry. As die motivering na inhoud en vorm reg is, sal die meeste gemeentes waarskynlik tot die insig kom dat hulle in baie opsigte anders funksioneer as die werklike doel van kerkwees. Die meeste gemeentes van die Nederduitsch Hervormde Kerk van Afrika sal na 'n deeglike evaluering tot die gevolgtrekking kom dat hulle in hoofsaak na binne gerig is en dat daar van uitbou by hulle feitlik niks tereg kom nie.

Sodra 'n gemeente insig in sy wese het, is daar gewoonlik 'n begeerte om te verander om te wees soos hy reeds in Christus is. Op hierdie stadium is dit nodig om 'n deeglike ontleding van die gemeente se situasie te maak. Dit kan geskied met behulp van ' $n$ fasiliteerder van buite die gemeente en die benutting van ongeveer sestig lidmate wat alle fasette van die gemeente se werk verteenwoordig (beplanningsgroep).

\subsubsection{Doel en missie}

Voordat opbou of verandering kan plaasvind, moet die gemeente 'n noukeurige opname van sy huidige situasie maak. Hierdie situasie-ontleding kan alleen plaasvind as daar bepaalde kriteria is waaraan gemeet kan word. In feite beteken dit dat die situasie primêr bepaal moet word aan die hand van die doel van kerkwees.

Die kerk is in die wêreld ter wille van die evangelie van Jesus Christus (Velthuysen 1988:504). Uit Matteus 28:16-19 en Handelinge 1:9 is dit duidelik dat die kerk in die wêreld geplaas is om die evangelie van Jesus Christus aan die hele wêreld te verkondig. Hierdie missionêre roeping word volvoer deur die woord en die daad van gelowiges. 
Die na buite-gerigtheid van die kerk is alleen moontlik as daar volgens Efesiërs 4:11-16 'n gelyktydige gerigtheid na binne is. Daar is nie sprake van ' $n$ voorrang van die een bo die ander nie. Uit genoemde en ander teksverse formuleer Nel die doel van kerkwees as drie-dimensionele diens: aan God, aan mekaar en aan die wêreld deur lidmate en ampsdraers. Hierdie diens het as fondament en is alleen moontlik deur die werk van God in Jesus Christus deur die Heilige Gees (Nel 1994:37). Volgens die Heidelbergse Kategismus (Vraag en Antwoord 54 en 55) het God die kerk in die wêreld geplaas om uit die hele mensegeslag vir Hom 'n gemeente te versamel en te bewaar vir die ewige lewe en dat elkeen wat deel is van hierdie gemeente, deel het aan Christus en al sy gawes en verplig is om as lewende lidmaat sy gawes ten dienste van die ander aan te wend. Op voetspoor van Henau, Bohren en ander beskryf Pieterse die kerk as liggaam van Christus wat deur middel van die kerugma, die diakonia en die koinonia die heil van Christus aan die wêreld moet verkondig (Pieterse 1990:23). Firet (1979:88) onderskei verder tussen kerugma en didache. Vir die Nederduitsch Hervormde Kerk van Afrika is die roeping van die kerk die verkondiging van die evangelie van Jesus Christus deur die apostolaat, die pastoraat en die diakonaat (Notule, Algemene Kerkvergadering 1995, bl 19). Samevattend kan die doel van die kerk beskryf word as om tot eer van God te leef deur die kommunikering van die evangelie van Jesus Christus in diens van God, van mekaar en van die wêreld deur middel van die kerugma, die didache, die diakonia en die koinonia.

Om uit te kom by die doel van die kerk, doen die beplanningsgroep Bybelstudie oor die kerngedeeltes wat op die wese van die kerk fokus, sodat ontdek kan word wat die Bybel oor die kerk leer.

In die lig van die breë doel van kerkwees formuleer die beplanningsgroep vir hulle gemeente 'n visie. 'n Visie kan beskryf word as 'n kort duidelik geformuleerde belydenis wat ' $n$ bepaalde groep as hulle roeping aanvaar. Dit moet vir ' $n$ gemeente op die algemene doel van kerkwees gegrond wees (Burger 1991:17-70). In die loop van die ontledingsfase en die latere beplanning, word voortdurend gewerk aan die formulering van die visie tot 'n finale produk wat die gemeente se goedkeuring wegdra. Voorbeelde van gemeentelike visies is onder andere die volgende: ons gemeente leef tot eer van God na bo, na binne en na die wêreld; ons is 'n gemeente wat uit liefde God, die wêreld en mekaar dien.

\subsubsection{Gemeente-ontleding}

Gemeente-ontleding, of beter bekend as gemeente-analise, is basies dieselfde as wat deur die opvoedkundiges situasie-ontleding genoem word (Dingemans 1986:247; Beukes 1983:188; Strydom 1981:20). 'n Gemeente-ontleding is 'n wetenskaplike, siste- 
matiese, kontroleerbare wyse waarop 'n gemeente verskillende aspekte van sy situasie, strukturering, identiteit en effektiwiteit ontleed om daarmee in die lig van die reeds geformuleerde doel van kerkwees oor sy wese en roeping te besin (Van der Walt 1993: 965). Waar Hendriks (1992:128-182) die gemeente-ontleding oor 'n baie breë linie laat loop, beperk Nel (1994:149-180) dit tot gemeenteprofiel, omgewingsdiagnose en gemeentelike bediening en programme. Callahan (1987:1) kombineer die drie fasette en hanteer dit in 'n eenheidsanalise. Waar Hendriks se omvattende proses kan lei tot 'n 'analysis paralysis', kan Callahan se oorvereenvoudigde proses weer lei tot 'n meting waar die kwantitatiewe oorheers. Met die oog op evaluering van slegs die noodsaaklike en die wesenlike sal dit waarskynlik die beste wees om die drie hoofkomponente van Nel in die ontledingsproses te behou.

Verskillende wyses van ontleding kan benut word. Die bekendste is: vraelyste, onderhoude, visitasie en verslaggewing, soos onder andere jaarliks aan die ringsvergadering. Die effektiefste is waarskynlik 'n proses waar die grootste gedeelte deelnemende besluitneming deur die gemeente plaasvind.

\subsubsection{Gemeenteprofiel}

Aangesien die meeste gegewens wat hier benodig word, statisties van aard is, kan een persoon dit versamel en tydens die ontledingsessie aan die groep voorhou. Van die belangrikste aspekte is hier: ouderdomsprofiel, lidmaattal, onderwyspeil, inkomsteverspreiding, huidige betrokkenheid van gemeentelede ten opsigte van: evangelisasie, sending, eredienste, kategese, Bybelstudie, jeugbediening, werkgroepe, diensgroepe, offergawe, barmhartigheidsdiens, onderlinge omgee vir mekaar (diakonia) en bereidheid om cip die kerkraad te dien. Hierdie profiel behoort oor die afgelope vyf jaar se inligting saamgestel te word. Die data wat in hierdie proses versamel is, word deur die beplanningsgroep in die lig van 'n vereenvoudigde SWOT-analise (Hendriks 1992:270) ontleed in die lig van die reeds geformuleerde doel. Die twee kernvrae sou dan wees: watter van hierdie gegewens sal met die oog op verwesenliking van die gemeentedoel helpend of remmend wees.

\subsubsection{Omgewingsprofiel}

Die gemeente se hede en toekoms is onlosmaaklik verbonde aan die samelewing en omgewing waarin hy funksioneer (Smit 1972:87-177; Dekker 1971:6-14). Op dieselfde wyse as die gemeenteprofiel word die volgende kerndata van die eksterne omgewing gehanteer: demografiese faktore, ekonomiese faktore, politieke faktore en godsdienstige faktore. 


\subsubsection{Gemeentelike bediening}

Aangesien hierdie die belangrikste deel van die ontleding is, behoort dit in diepgang hanteer te word. Verskillende wyses van evaluering is moontlik: 'n vraelys wat deur elke deelnemer voltooi word en daarna in klein- en grootgroepe bespreek word; 'n lys van positiewe aanwysers wat self deur die groep geformuleer word en evaluasie in die lig daarvan of op voetspoor van Callahan 'n lys wat die kernaspekte van 'n bepaalde bediening formuleer met ' $n$ puntewaarde-evaluasie. In die lig van genoemde data besin die beplanningsgroep oor die volgende: hoe gaan dit regtig in die gemeente? waarom is die funksionering positief of negatief? wat is die kernprobleem? watter oplossings is moontlik? Ten minste die volgende moet deur die beplanningsgroep geëvalueer word: gerigtheid van die gemeente na buite, erediens, kategese, pastorale besoeke deur ampsdraers en lidmate, onderrig en toerusting, jeugbediening, werkgroepe en diensgroepe, funksionering van die kerkraad, koinonia en barmhartigheidsdiens.

\subsubsection{Doelstellings, doelwitte en aksieplanne}

In die lig van die ontleding, met die breë doelstelling van kerkwees in gedagte, word vir elke afdeling van die bediening doelstellings, doelwitte en aksieplanne geformuleer.

Die totale bediening is so breed dat nie gelyktydig aan alle fasette aandag gegee kan word nie. Prioriteite moet vasgestel word. Begin liewer met te min stadig as met te veel te oorhaastig.

Nadat die beplanningsgroep prioriteite vasgestel het, word 'n kleiner werkgroep aangewys vir die afhandeling en deurlopende begeleiding van die proses (werkgroep kerkbestuur).

Die werkgroep kerkbestuur formuleer breë doelstellings vir elke afdeling van die bediening. Hierdie doelstellings word na die kerkraad, ouderlingevergadering, diakensvergadering en afsonderlike werkgroepe en diensgroepe deurgegee om dit tot enkele kerndoelwitte te verfyn. Doelstellings is breë omskrywings van wat bereik wil word. Doelwitte is spesifieke, meetbare, konkrete, bereikbare, realistiese en aan tyd gekoppelde beskrywings van wat beoog word (Beukes 1985:159; Dingemans 1986:223; Callahan 1987:44). Om die doelwitte te bereik, bedink elke afdeling van die bediening aksieplanne en meetinstrumente.

\subsection{Organisering, leiding en kontrole}

Elke afdeling van die bediening beplan sy eie organisering, leiding en kontrole. Met die oog op koördinering word deurlopend aan die werkgroep kerkbestuur terugvoering gegee. Laasgenoemde doen deurlopend aan die ouderlinge- en diakensvergadering verslag met die oog op deurgee van gegewens aan die kerkraadsvergadering. 


\section{Literatuurverwysings}

Beukes, M J du P 1983. Kategese: 'n Handleiding vir kategete. Pretoria: Kital.

- 1985. Die toepasbaarheid van $\mathbf{R}$ A Kruger se 'Beginsels en kriteria vir kurrikulumontwerp vir kategese', in Smuts, A J (red), Die Woord aan die werk, 154170. Pretoria: NG Kerkboekhandel.

Bisschoff, J H 1991: Gemeentebou: 'n Prakties-Teologiese basisteorie. DD-proefskrif, Universiteit van Pretoria.

Bons-Storm, $\mathbf{R}$ 1987. Geloofwaardig stappen op de weg van gemeenteopbouw. Den Haag: Boekencentrum.

Botha, P J E 1985. 'n Prakties-teologiese ondersoek na 'n konsep vir gemeenteadministrasie vanuit die perspektief van die opsig, toesig en tug. BD-skripsie, Universiteit van Pretoria.

Breytenbach, J H 1991. Die inhoud en die doel van die Nederduitsch Hervormde Kerk se bediening, met verwysing na die ampte. HTS 47/2, 332-353.

Burger, C 1991. Gemeente en bediening: Die dinamika van 'n Christelike geloofsgemeenskap - nuut gedink oor gemeentes. Pretoria: Lux Verbi.

Callahan K L 1986. Twelve keys to an effective church: The leaders guide. San Francisco: Harper.

- 1987. Twelve keys to an effective church: The planning workbook. San Francisco: Harper.

- 1994. Visiting in an age of mission: $A$ handbook for person-to-person ministry. San Francisco: Harper.

Dekker, G 1971. Over de betekenis van de sociologie voor de kerk. Ministerium Tijdschrift voor Praktische Theologie en Ambtelijke Praktijk 5/2, 6-16.

Dingemans, G D J 1986. In de leerschool van het geloof, mathetiek en vakdidactiek voor catechese en kerklijk vormingswerk: Handboek Praktische Theologie. Kampen: Kok.

Dreyer, J G M 1986. Building up the body of Christ. A project submitted to the Faculty of Westminster Theological Seminary in partial fulfillment of the requirements for the degree doctor of ministry.

- 1987. Evaluasie van verskillende gemeenteboumodelle. Praktiese Teologie in Suid-Afrika II, 54-71.

Firet, J 1977. Het agogisch moment in het pastoraal optreden. Kampen: Kok.

Hendriks, J 1992. Strategiese beplanning in die gemeente: Die beginsels en praktyk van gemeentevernuwing. Wellington: Hugenote Uitgewers.

Herbst, M 1988. Missionarischer Gemeindeaufbau in der Volkskirche. Stuttgart: Calwer. 
Heyns, L 1993. Bestuur van die gemeente as organisasie van vrywilligers. Praktiese Teologie in Suid-Afrika 8/2, 126-136.

Kuyper, A 1909. Encyclopaedie der Heilige Godsgeleerdheid, Derde deel. Bijzonder deel. Kampen: Kok.

Kruger, R A 1980. Beginsels en kriteria vir kirrukulum ontwerp. Pretoria: HAUM.

Lissenburg, D 1978. Veranderen in de kerk - hoe doe je dat? Assen: Van Gorcum.

Louw, D J 1989. Gesinsverryking: Riglyne vir groei en kommunikasie. Pretoria/ Kaapstad: Academia.

Möller, C 1987. Lehre vom Gemeindeaufbau, I: Konzepte, Programme, Wege. Göttingen: Vandenhoeck.

Nel, M 1987. Teologiese perspektiewe op gemeentebou. Pretoria: NG Kerkboekhandel.

- 1988. Fases in gemeentebou. Pretoria: NG Kerkboekhandel.

- 1993. Gemeentebou: Dinamiese kragte en die vernuwingsproses. Praktiese Teologie in Suid-Afrika 8/2, 115-125.

- 1994. Gemeentebou. Pretoria: Orion.

Pieterse, H J 1990. 'n Erediens-uitsig op die gemeente, in Smuts, A J, Vos, C J A, Nel, M (reds), Gesprek oor die erediens: Teologiese huldigingsbundel aan A C Barnard, 22-39. Pretoria: NG Kerkboekhandel.

Raubenheimer, O S H 1987. Persone en instansies betrokke by gemeentebou. Praktiese Teologie in Suid-Afrika II, 38-53.

Ridderbos, H 1973. Paulus: Ontwerp van zijn theologie. Kampen: Kok.

Rossouw, P J 1990. Bedieninge in verskillende kerklike tradisies met verwysing na spesifieke paradigmas. Praktiese Teologie in Suid-Afrika 5/1, 43-60. Pretoria: NG Kerkboekhandel.

Smit, P 1972. Godsdienst en kerk in het licht van de sociologie: Praktisch Theologische handboekjes. Den Haag: Boekencentrum.

Strydom, A H 1981. Die suksesvolle dosent. Goodwood: Nasou.

Te Velde, M 1989. Gereformeerde gemeenteopbouw: Een eerste koersbepaling voor een nieuw theologisch vak. Barneveld: De Vuurbaak.

Van der Walt, B J \& Beukes, M J du P 1993. Op pad na 'n nuwe bedieningstruktuur: 'n Analise van die gemeente as deel van hierdie proses. HTS 49/4, 963-986.

Velthuysen, G C 1988. Die wese van die kerk: 'n Teologiese antwoord op 'n filosofiese vraag. HTS 44/2, 489-513. 